\title{
Aktivitas Antibakteri Pada Senyawa Turunan Kalkon Hasil Sintesis Dari Miristisin Buah Pala
}

\section{Antibacterial Activity of Kalkon Derivative Compounds from Miristisin Nutmeg}

\author{
Anita Nilawati ${ }^{1}$, Hery Muhammad Ansory ${ }^{1}$ \\ ${ }^{1}$ Fakultas Farmasi, Universitas Setia Budi \\ Jln. Letjen Sutoyo-Mojosongo Surakarta-57127, Indonesia \\ email : althavandyanita@yahoo.co.id
}

\begin{abstract}
ABSTRAK
Pala merupakan tanaman rempah asli Indonesia yang selama ini hanya digunakan untuk keperluan pangan seperti bumbu dan rempah, serta industri makanan. Miristisin adalah senyawa khas penentu kualitas minyak pala dan memiliki beberapa gugus fungsional, yaitu alil, fenil, dan eter. Senyawa turunan kalkon merupakan metabolit sekunder golongan flavonoid yang dikenal mempunyai aktivitas biologi seperti antikanker, sitotoksik, antimikroba dan antimalaria. Sifat antibakteri berkaitan erat dengan struktur keton $\alpha, \beta$ tak jenuh substituen yang terikat pada kedua cincin aromatiknya, seperti gugus metilendioksi, metoksi, $\mathrm{Cl}, \mathrm{Br}, \mathrm{OH}$ dan lain sebagainya. Penelitian ini bertujuan untuk mengetahui aktivitas antibakteri senyawa turunan kalkon hasil sintesis dari miristisin buah pala.

Uji aktivitas antibakteri dilakukan terhadap bakteri Escheresia Coli (E. Coli) dan Staphylococcus Aureus (S. Aureus). Pengujian aktivitas antibakteri dilakukan dengan metode difusi agar dengan menggunakan cakram/disc dari larutan senyawa turunan kalkon dalam pelarut aseton dengan konsentrasi $1,25 \% ; 2,5 \%, 5 \%$ dan $10 \%$ dan menggunakan kontrol positif Ciprofloxacin $5 \mu \mathrm{g}$ dan control negative pelarut aseton. Hasil pengujian kemudian dihitung zona hambat dari masing-masing konsentrasi untuk menentukan aktivitas antibakteri.

Hasil uji antibakteri menunjukkan rata-rata diameter zona hambat larutan sampel pada konsentrasi $1,25 \% ; 2,5 \%, 5 \%$ dan $10 \%$ pada bakteri $E$. Coli berturut turut $13 \mathrm{~mm}, 19 \mathrm{~mm}, 22 \mathrm{~mm}$ dan $26 \mathrm{~mm}$, sedangkan pada bakteri $S$. Aureus berturut-turut $7 \mathrm{~mm}, 7 \mathrm{~mm}, 9 \mathrm{~mm}$ dan $19 \mathrm{~mm}$. Hasil uji tersebut menunjukkan serbuk turunan kalkon hasil sintesis dari miristisin buah pala menunjukkan semakin besar konsentrasi sampel, semakin besar aktivitas antibakterinya. Aktivitas antibaketri kuat ditunjukkan pada bakteri E.Coli dengan konsentrasi 10\%, sedangkan pada konsentrasi yang sama menunjukkan aktivitas sedang pada bakteri S.Aureus.
\end{abstract}

Kata Kunci : Uji aktivitas anti bekteri, difusi cakram, senyawa turunan kalkon, E.Coli, S.Aureus

\section{ABSTRAK}

Nutmeg is a native Indonesian herb that has been used for food purposes such as spices and herbs, and the food industry. Miristisin is a typical compound that determines the quality of nutmeg oil and has several functional groups like allyl, phenyl, and ether. Kalkon derived compounds are secondary metabolites of flavonoids that have biological activities such as anticancer, cytotoxic, antimicrobial and antimalarial. The antibacterial properties are closely related to the $\alpha, \beta$-unsaturated and the substituent of both aromatic rings, such as methylenedioxy groups, methoxy, $\mathrm{Cl}, \mathrm{Br}, \mathrm{OH}$ and so on. The aims of this study are to determine the antibacterial activity of kalkon derived from miristisin.

Antibacterial activity test was performed on Escheresia Coli (E. Coli) and Staphylococcus Aureus (S. Aureus) bacteria. Antibacterial activity test was done by diffusion method by using disc from kalkon derivative compound in acetone with $1,25 \% ; 2.5 \%, 5 \%$ and $10 \%$ of concentration. The positive control of Ciprofloxacin $5 \mu \mathrm{g}$ and negative control of acetone solvent. The inhibit zone of each concentration are determine the antibacterial activity. 
the result of antibacterial test showed inibition diameter zone at $1.25 \% ; 2.5 \%, 5 \%$ and $10 \%$ concentration in E. Coli bacteria were $13 \mathrm{~mm}, 19 \mathrm{~mm}, 22 \mathrm{~mm}$ and $26 \mathrm{~mm}$, respectively, whereas in S. aureus bacteria were $7 \mathrm{~mm}, 7 \mathrm{~mm}, 9 \mathrm{~mm}$ and $19 \mathrm{~mm}$, respectively. The results of the test showed the greater of sample concentration, the greater antibacterial activity. Strong antibacteria activity was shown in E.Coli bacteria with concentration of $10 \%$, while at the same concentration showed moderate activity in S.Aureus bacteria.

Keywords: Antibacterial activity test, disc diffusion, kalkon derived compound, E.Coli, S.Aureus

\section{Pendahuluan}

Indonesia merupakan negara penghasil pala terbesar didunia dengan total produksi $76 \%$ dari keseluruhan produksi pala. Pala merupakan tanaman rempah asli Indonesia yang selama ini hanya digunakan untuk keperluan pangan serta industri makanan dalam negeri berupa manisan, selai dan sirup (Kardinan, 2005). Seluruh bagian buah pala seperti biji, fuli maupun daging buah dapat diolah menjadi minyak pala. Minyak pala sendiri memiliki berbagai kegunaan seperti untuk mengobati rematik, sakit perut, masuk angin, dan insomnia. Kegunaan minyak pala ini tidak terlepas dari kandungan kimia yang terdapat dalam minyak pala yaitu a-pinen (20\%), miristisin (6-8\%), serta komponen lainya (Sohilait, 2010).

Miristisin adalah senyawa khas yang terdapat dalam minyak pala dan merupakan penentu kualitas minyak pala (Friyadi, 2002). Miristisin merupakan senyawa alam yang menarik karena memiliki beberapa gugus fungsional, yaitu alil, fenil, dan eter. Senyawa turunan kalkon merupakan metabolit sekunder golongan flavonoid yang dikenal mempunyai aktivitas biologi seperti antikanker (Achanta et al, 2006), sitotoksik (Echeverria et al, 2009), antimikroba (Bhuiyan, 2011) dan antimalaria (Wu et al, 2002). Sifat antibakteri berkaitan erat dengan struktur keton $\alpha, \beta$ tak jenuh (Lahtchev et al, 2008).

Sifat antibakteri senyawa kalkon terikat pada kedua cincin aromatiknya, seperti gugus $\mathrm{Cl}, \mathrm{Br}, \mathrm{OH}$ dan lain sebagainya (Prasad et al, 2006). Namun, jika ditinjau dari asal-usul biogenetiknya, senyawa kalkon yang tersubstitusi halogen tidak mungkin dapat ditemukan di alam. Oleh karena itu, untuk mendapatkan kalkon tersubstitusi halogen dilakukan dengan cara sintesis. Berdasarkan uraian tersebut, maka dilakukan sintesis turunan kalkon dari miristisin hasil isolasi dari minyak pala dan kemudian dilakukan uji aktivitas antibakteri terhadap bakteri Escheresia Coli dan Staphylococcus Aureus.

Permasalahan yang dibahas dalam penelitian ini meliputi (1) Apakah senyawa turunan kalkon hasil sintesis dari miristisin buah pala dapat digunakan sebagai senyawa antibakteri? (2) Berapa konsentrasi senyawa turunan kalkon hasil sintesis dari miristisin buah pala yang mempunyai aktivitas sebagai antimikroba? (3) Berapa nilai diameter zona hambat yang dimiliki senyawa turunan kalkon hasil sintesis dari miristisin buah pala?

Sedangkan tujuan penelitian ini adalah (1) Mengidentifikasi kemampuan senyawa turunan kalkon hasil sintesis dari miristisin buah pala sebagai 
senyawa anti bakteri. (2) Mengetahui konsentrasi senyawa turunan kalkon hasil sintesis dari miristisin buah pala yang mempunyai aktivitas antibakteri, dan (3) Mengetahui diameter zona hambat yang dimiliki senyawa turunan kalkon hasil sintesis dari miristisin buah pala.

\section{Metode Penelitian Tempat dan Waktu Penelitian}

Uji aktivitas antibakteri dilakukan di Laboratorium Mikrobiologi Universitas Setia Budi Surakarta. Penelitian ini berlangsung selama lebih kurang 1 bulan.

\section{Alat dan Bahan}

Alat-alat yang digunakan yang digunakan dalam penelitian ini antara lain inkas, jarum ose, kapas steril, pinset, autoklaf, inkubator, kotak septis, cawan petri, kaca obyek, deck glass, dan mikroskop.

Bahan-bahan yang digunakan adalah serbuk turunan kalkon hasil sintesis dari miristisin buah pala, akuades, nutrient agar, nutrient Broth, aseton p.a dan cakram antibiotik (Ciprofloxacin). Bakteri uji yang digunakan dalam penelitian ini adalah Escherechia coli (Gram negatif), dan Stapyhlococcus aureus (Gram positif). Bakteri yang digunakan diperoleh dari koleksi Laboratorium Mikrobiologi Universitas Setia Budi Surakarta.

\section{Prosedur Kerja}

Uji aktivitas antibakteri metode difusi agar

\section{a. Peremajaan bakteri uji}

Media yang digunakan untuk uji antibakteri yaitu NA (nutrient agar). NA sebanyak 20 gram dilarutkan dalam $1000 \mathrm{~mL}$ aquades dan dimasukkan ke dalam tabung reaksi, masing-masing sebanyak $15 \mathrm{~mL}$. Media ditutup dan disterilisasi pada suhu $121^{\circ} \mathrm{C}$ dan tekanan 15 psi selama 15 menit (Capuccino \& Suherman, 2011). Peremajaan mikroba bertujuan untuk meremajakan kembali bakteri (Escherichia coli dan staphylococcus aureus dari agar miring ke dalam larutan NB. Media NB yang telah dibuat dimasukkan ke dalam tabung reaksi dan disterilisasi. Bakteri dari agar miring diambil dengan menggunakan jarum ose steril, kemudian diinokulasi ke dalam media NB. Tabung ditutup dengan kapas kemudian diinkubasi dalam inkubator pada suhu $37^{\circ} \mathrm{C}$ selama 24 jam (Capuccino \& Suherman, 2011).

\section{b. Uji aktivitas antibakteri}

Media dipanaskan sampai mencair dan didinginkan pada suhu $50^{\circ} \mathrm{C}$ dalam waterbath, kemudian ditambahkan $1 \mathrm{~mL}$ biakan bakteri Escherichia coli dan Staphylococcus aureus (OD $600 \mathrm{~nm}$ $0,1)$ ke dalam tabung, kemudian dihomogenkan dan dituang ke dalam cawan petri. Setelah media memadat, kertas cakram yang telah ditetesi dengan sampel uji (konsentrasi 1,25\%; $2,5 \% ; 5 \%$ dan $10 \%$ dalam pelkarut aseton) diletakkan diatas media agar. Kontrol positif yang digunakan yaitu Ciprofloxacin dengan konsentrasi 1 $\mathrm{mg} / \mathrm{mL}$ dan kontrol negatif yaitu aseton yang digunakan untuk melarutkan sampel. Cawan petri diinkubasi dalam inkubator pada suhu $37^{\circ} \mathrm{C}$. Diameter daerah hambat pertumbuhan bakteri diukur setelah diinkubasi selama 24 jam.

\section{HASIL DAN PEMBAHASAN}

Uji aktivitas antibakteri terhadap senyawa turunan kalkon hasil sintesis 
dari miristisin buah pala dilakukan dengan menggunakan metode difusi agar. Prinsip metode ini yaitu sampel uji berdifusi langsung ke media agar yang mengandung bakteri uji dengan nilai OD 0,1 . Adanya aktivitas antibakteri ditandai dengan terbentuknya zona bening disekitar sampel uji. Konsentrasi sampel uji yang digunakan yaitu 1,25\%; 2,5\%; $5 \%$ dan 10\%. Sampel uji dilarutkan dalam aseton. Pengujian dengan berbagai tingkat konsentrasi bertujuan untuk mengetahui apakah kenaikan konsentrasi akan meningkatkan aktivitas antibakterinya. Aseton juga berfungsi sebagai kontrol negatif dan antibiotik Ciprofloxacin dengan konsentrasi $10 \mu \mathrm{g} / \mathrm{mL}$ digunakan sebagai kontrol positif. Molekul senyawa kalkon mempunyai gugus etilen keto ($\mathrm{CO}-\mathrm{CH}=\mathrm{CH}-$ ) yang bersifat reaktif. Gugus inilah yang diperkirakan menyebabkan molekul kalkon mempunyai berbagai macam aktivitas biologis dimana salah satunya sebagai antibakteri). Selain itu, sifat antibakteri senyawa kalkon juga dipengaruhi oleh jenis substituen yang terikat pada kedua cincin aromatiknya (Prasad et al, 2006).

Hasil uji antibakteri senyawa kalkon hasil sintesis dapat dilihat pada Tabel 1. Senyawa Kalkon menunjukkan aktivitas terhadap bakteri E.coli (Gram negatif) dan S.aureus (Gram Positif) yang ditandai dengan adanya zona bening pada media agar yang berarti senyawa dapat menghambat atau membunuh bakteri. Diameter zona bening yang dihasilkan oleh senyawa turunan kalkon terhadap bakteri E.Coli (Gram negative) berkisar antara 13-26 $\mathrm{mm}$ dan terhadap bakteri S.Aureus (Gram positif) berkisar antara 7-19 mm.
Menurut Saxena dan Gomber (2008) diameter zona bening atau zona hambat $>20$ memiliki aktivitas kuat, diameter hambat $16-20 \mathrm{~mm}$ memiliki aktivitas sedang, diameter hambat 10-15 mm memiliki aktivitas lemah, dan diameter hambat $<10 \mathrm{~mm}$ memiliki aktivitas sangat lemah.

Hasil uji antibakteri menunjukkan

bahwa semakin besar konsentrasi sampel, mempunyai aktivitas antibaketri yang seamkin besar pula. Senyawa turunan kalkon hasil sintesis dari miristisin buah pala pada konsentrasi $10 \%$ memiliki aktivitas tergolong kuat terhadap bakteri $E$. Coli dan tergolong sedang pada bakteri $S$. Aureus. Senyawa kalkon hasil sintesis dari miristisin buah pala memiliki gugus keton $\alpha, \beta$ tak jenuh yang bertindak sebagai antibakteri, hal ini sesuai dengan hasil penelitian Lahtchev et al., 2008 yang menyatakan senyawa kalkon dapat bertindak sebagai antibakteri dikarenakan adanya gugus keton $\alpha, \beta$ tak jenuh. Selain itu, sifat antibakteri senyawa kalkon juga tergantung pada jenis substituen yang terikat pada kedua cincin aromatiknya. Gugus klorida dikenal mempunyai aktivitas antibakteri yang cukup baik (Prasad et al, 2006). Senyawa kalkon hasil sintesis memiliki gugus keton $\alpha, \beta$ tak jenuh yang bertindak sebagai antibakteri, hal ini sesuai dengan hasil penelitian Lahtchev et al., 2008 yang menyatakan senyawa kalkon dapat bertindak sebagai antibakteri dikarenakan adanya gugus keton $\alpha, \beta$ tak jenuh. Selain itu, sifat antibakteri senyawa kalkon juga tergantung pada jenis substituen yang terikat pada kedua cincin aromatiknya. Gugus klorida dikenal mempunyai 
aktivitas antibakteri yang cukup baik (Prasad et al, 2006).

Pada penelitian ini, bakteri Gram negatif lebih sensitif dibandingkan Gram positif. Hal ini kemungkinan disebabkan oleh, perbedaan ketahanan bakteri karena adanya perbedaan alamiah antara kedua golongan bakteri. Pada bakteri Gram positif senyawa kurang sensitive kemungkinan dikarenakan tidak terdapatnya reseptor spesifik (molekul protein yang menerima sinyal kimia) untuk masuknya senyawa uji ke dalam sel bakteri Gram positif (Russell, 1991). Bakteri Gram positif memiliki lapisan peptidoglikan yang tebal dibandingkan bakteri Gram negatif (Beveridge., 1997 dalam Juliantina, 2008), hal ini juga kemungkinan yang menyebabkan bakteri Gram positif kurang sensitif terhadap senyawa uji.

Ciprofloxacin termasuk

golongan antibiotika $\beta$-laktam yang aktif terhadap bakteri Gram positif maupun Gram negatif dengan spektrum bervariasi. Antibiotik fluokinolon bekerja membunuh bakteri dengan cara menginhibisi sintesis dinding selnya. Pada proses pembentukan dinding sel, terjadi reaksi transpeptidasi yang dikatalis oleh enzim transpeptidase dan menghasilkan ikatan silang antara dua rantai peptida-glukan. Enzim transpeptidase yang terletak pada membran sitoplasma bakteri tersebut juga dapat mengikat antibiotic $\beta$-laktam sehingga menyebabkan enzim ini tidak mampu mengkatalisis reaksi transpeptidasi walaupun dinding sel terus dibentuk. Dinding sel yang terbentuk tidak memiliki ikatan silang dan peptidoglikan yang terbentuk tidak sempurna sehingga lebih lemah dan mudah terdegradasi. Pada kondisi normal, perbedaan tekanan osmotik di dalam sel bakteri Gram negatif dan di lingkungan akan menyebabkan lisis sel. Selain itu, kompleks protein transpeptidase dan antibiotik fluokinolon akan menstimulasi senyawa autolysin yang dapat mendigesti dinding sel bakteri tersebut. Dengan demikian, bakteri yang kehilangan dinding sel maupun mengalami lisis akan mati (kokfai et al, 2009).

\section{KESIMPULAN}

Berdasarkan hasil penelitian dapat disimpulkan sebagai berikut:

1. Senyawa turunan kalkon hasil sintesis dari miristisin buah pala memiliki aktivitas anti bakteri baik pada bakteri Escheresia Coli maupun bakteri Staphylococcus Aureus.

2. Kenaikan konsentrasi sampel uji menunjukkan aktivitas yang turut meningkat pula.

3. Pada konsentrasi sampel $10 \%$ memiliki aktivitas antibaketri yang tergolong kuat pada bakteri E. Coli dan sedang pada bakteri $S$. Aureus.

\section{Daftar Pustaka}

Achanta, G., Modzelewska, A., Feng, L., Khan, S.R., \& Huang, P., 2006, Boronic Chalcone Derivative Exhibits Potent Anticancer Activity Through Inhibition of The Proteosome, Molecular Pharmacol, 70.426-433.

Agusta.A., 2000, Minyak Atsiri Tumbuhan Tropika Indonesia, ITB, Bandung

Bhuiyan, M.M.H., Hossain, M.I., Mahmud, M.M., \& Amin, M.A., 2011, Microwave-assisted 
efficient shynthesis of chalcones as probes for antimicrobial activities, Chemistry Journal, Vol. 01, pp.21-28.

Brown, K. C dan Chang, V. S., 1982, The Oxidation of The terminal Alkenes by Permanganate, J. Chem. Educ., 8:696-697

Capuccino \& Suherman, 2011, Microbiology a laboratory manual, 9th Edition, SUNY Roccland Community College, Canada.

Kardinan, 2005, Tanaman Penghasil Minyak Atsiri, Agro Media Pustaka, Jakarta.

Lahtchev, K.L., Batovska, D.I., Parushev, St.P., Ubiyvovk, V.M., \& Sibirny, A.A., 2008, Antifungal Activity of Chalcones : A mechanistic Study Using Various Yeast Strains, European journal of Medicinal Chemistry, 43 : 2220-2228.

Mandge, S., Singh, H. P., Dutta G, S dan Moorthy, N. S., 2007, Synthesis and Characterization of Some Chalcone Derivatives, Trends Apl. Sci. Res., 2, 1, 52-56

Nurdian. Y., 2003, Efek Trimiristin Terhadap Respon Meliuk Akibat Stimulasi Asam Asetat pada Mencit, Jurnal ilmu dasar, Vol. 4, No. 2, hal 99-103

Ohkatsu, Y dan Satoh, T., 2007, Antioxidant and Photoantioxidant Activities of Chalcone Derivatives, Journal of the Japan Petroleum Institute, 51(5), 298-308

Oko. S., 2012, Sintesis senyawa $p$ metoksibenzil asetat dan $p$ metoksibenziltiol asetat dari minyak adas dengan metode sonikasi, gelombang mikro dan penggerusan, Tesis-FMIPA UGM, Yogyakarta

Prasad, Y.R., Kumar, P.R., Deepti, C.A., \& Ramana, M.V., 2006, Synthesis and Antimicrobial Activity of Some Novel Chalcones of 2-hydroxoumarin, E-Journal of Chemistry, 3(13): 236-241.

Rahayu, 2002, Pemanfaatan anetol dalam minyak adas untuk pembuatan turunan antibiotik C-9154, Tesis-FMIPA UGM, Yogyakarta

Sastrohamidjojo, H., 2004, Kimia Minyak Atsiri, Gadjah Mada University Press, Yogyakarta.

Sohilait, M., 2010. Sintesis Senyawa Tabir Surya 3,4-Metilendioksi Isoamil Sinamat Dari Safrol Hasil IsolasiMinyak Kulit Lawang. Skripsi-UNPATTI, Ambon.

Tiwari, B., Pratapwar, A. S., Tapas, A. R., Butle, S. R dan Vatkar, B. S., 2010, Synthesis dan Antimicrobial Activity of Some Chalcone Derivatives, Int.J. Chem.Tech Res., Vol.2, No.1, 499-503

Wu, J.H., Wang, X.H., Yi, Y.H., \& Lee, K.H., 2003, Anti-AIDS Agents 54 A potents anti-HIV Chalcone and Flavonoids from Genus Desmos, Bioorg. Med. Chem. Lett., 13 (10), pp 813-1815. 